\title{
The Testing of Stanley Kunitz
}

\author{
Marjorie G. Perloff
}

Stanley Kunitz has always been a poet's poet. Editor, translator, anthologist, professor, director of the Poetry Center of the YMHA in New York, he has numbered among his close friends and admirers the two most celebrated poets of his generation: Robert Lowell and Theodore Roethke. When Kunitz gathered together his best poems of thirty years for the Selected Poems of 1959, James Wright called him "one of the finest American poets of the century, and remarked, "The truth is that 53-year old Stanley Kunitz is just beginning." It is no wonder, then, that when The Testing Tree, Kunitz's first volume of poetry in thirteen years, and a slim one at that (sixty-seven pages including the author's notes as well as seven translations from the Russian), was published earlier this year, it was greeted enthusiastically by the Poetic Establishment. Lowell, who gave The Testing Tree a generous tribute on the front page of the New York Times Book Review (March 21, 1971), is quoted on the book blurb as saying, "In these later poems, he again tops the crowd-he surpasses himself, the old iron brought to a white heat of simplicity. Call no man old who can grow."

Academic critics have been much less receptive to Kunitz's work. $\mathrm{He}$ is barely mentioned in the standard surveys of M. L. Rosenthal and Glauco Cambon, and his poems rarely appear in the fashionable anthologies. The standard critical view is that he is too derivative, too unoriginal to merit sustained attention. In the forties, so the argument runs, Kunitz wrote neat little rhyming stanzas full of clotted symbolism, metaphysical conceits, and Marvellian ironies, in keeping with the going convention one associates with the early Auden, with Ransom, Tate, or MacLeish. Then, in the later fifties, when Lowell, Snodgrass, and Berryman were discovering that there's more enterprise in walking naked, Kunitz predictably switched from a third-person, impersonal, neo-metaphysical mode to the new confessionalism of Life Studies and Heart's Needle. Despite his inventive verbal structures, in short, Kunitz has failed to create a style that is recognizably his own.

How can we reconcile these divergent views? The cynical will argue that when Lowell praises "the new style," the casting off of "the once redoubtable armor," he is simply looking into the mirror and admiring his own image. But then there are plenty of confessional poets around whom Lowell has not praised, and even Marius Bewley, who objected to the "verbal self-consciousness," "educated archaic ingenuity," and "tedious obscurity" of Kunitz's early verse, has remarked that the best poems in the 1959 volume are those later ones like "The Dragonfly" that avoid the metaphysical convention, working toward "a clarity and immediacy that comes directly from experience." It is just possible, then, that 66-year-old Stanley Kunitz has finally found a lyric mode that suits his 
native temperament. Yeats, after all, wrote his greatest poems after he was sixty.

One of the best examples of Kunitz's current poetic mode is the opening poem of The Testing Tree, "Journal for my Daughter," which is also one of Kunitz's most recent compositions (it first appeared in New American Review 9 in 1970). The genre of "Journal for my Daughter" is entirely traditional: it recalls Coleridge's "Frost at Midnight," Yeats's "Prayer for my Daughter," as well as such recent prototypes as Lowell's Harriet sonnets and Snodgrass's poems about divorce in After Experience. But "Journal for my Daughter" is not merely imitative. Unlike Lowell and Snodgrass, whose little daughters merely serve as stimuli to prompt their poet-fathers' meditations, Kunitz gives a good deal of weight to the daughter's own perspective. Thus, although the speaker poses as worldly sophisticate, he comes to recognize that he is, in the final analysis, the good Jewish father as nebbich. He gets, in other words, no more than he deserves.

The poem has nine sections of unequal length. Here is the first:

Your turn. Grass of confusion.

You say you had a father once:

his name was absence.

He left but did not let you go.

Part of him, more than a shadow,

beckoned down corridors,

secret, elusive, saturnine,

melting at your touch.

In the crack

of a divided house

grew the resentment weed.

It has white inconspicuous flowers.

Family of anthologists!

Collectors of injuries!

The dramatic opening-"Your turn"-immediately draws the reader into the situation: the debate between father and daughter is evidently one of long standing, and although they continue to go through the motions of discussion, they are hopelessly deadlocked. "Grass of confusion" suggests not only that the daughter's mental landscape, like the poet's own, is full of weeds, but that she is, or has just been, smoking marijuana, so that her current outburst is prompted by a momentary lack of inhibition. Kunitz does not press this meaning, but it ties in with the "tranquillizing song" the father once sang to his baby daughter (Part 4), to the image of the drunken poets in Part 5, and to the baby's voice, "drugged with milk and sleep," in Part 8. The young girl's current irritation is rooted in the central contradiction of her family situation: despite her parents' divorce ("a divided house"), Daddy still wants to run her life. The last two lines, moreover, suggest in their comic allusion to Rimbaud's "Drôle de ménage!" that both father and daughter take a certain delight in collecting "injuries" in their mental anthologies: suffering all too easily becomes a way of life.

The thematic import of this verse paragraph is, however, less remarkable 
than is its carefully wrought sound structure. In Selected Poems, the predominant verse forms are two: the iambic tetrameter or pentameter quatrain and blank verse. Both have a slightly redolent air. In the quatrain poems, for example, the regular iambic beat puts heavy emphasis on the rhymes, an emphasis that the chosen rhyme words often fail to sustain:

My wisdom, ripe with body's ruin, found

Itself tart recompense for what was lost

In false exchange: since wisdom in the ground

Has no apocalypse or pentecost.

It is difficult to justify the awkward break between "found" and "itself" except to say that the quatrain form demands it. More important, the rhyme "lost"/ "pentecost" seems unnecessarily cute, for it is quite enough to say that, once dead, our "wisdom" can have no apocalypse without throwing in the Pentecost for good measure.

Or to take another example, this time from The Testing Tree: in "Three Floors" (1962), there is an uneasy alliance between the neat, chiselled rhyming quatrain and the new confessional mode:

Sister's doughboy on last leave
had robbed me of her hand;
downstairs at intervals she played
Warum on the baby grand.

That the little boy feels "robbed" of his mother's hand has no connection with the information that she plays on a "baby grand" rather than on, say, a concert grand or an upright, and so the obtrusive, clinching rhyme seems distracting and slightly coy.

The weight of the blank verse tradition seems to be equally inhibiting for Kunitz; one notices that his strict blank verse poems contain frequent awkward inversions or other obsolete syntactic constructions:

Mile after mile I followed, with skimming feet,

After the secret master of my blood,

Him, steeped in the odor of ponds. . . .

... I touch you cold, unstirring, star-bemused,

That are become the land of your self-strangeness. . . .(SP, 3)

I tend the last light shining on the farms

And keep for you the thought of love alive. . . .

"Journal for my Daughter" is written in free verse, but its base rhythm is the three-stress line one associates with Yeats's "Easter 1916" or Auden's "September 1939." It is an extremely difficult form to master because each short line 
calls attention to itself and there are only so many places where the primary stress can fall. In Part I of "Journal," Kunitz plays countless variations on his three-stress line norm: the lines range from one stress ("in the cráck") to four ("He léft but díd not lét you gó"). Instead of forcing the words to fit into a preconceived mold as in the quatrain or blank verse poems, Kunitz now lets tone and meaning determine the metrical variations. The first line, for example, uses secondary stressing, a strong caesura, and a feminine ending to emphasize the conflict between father and daughter: "Yóur tûrn.// Gráss of confúsion." This purposely stumbling line is followed by an irregular couplet, in which the lines are tied together by the merest echo of rhyme ("once"/ "absence"), and the lilting iambic tetrameter of the first ("You sáy you hád a fáther ónce") is undercut by the foreshortened second line with its two primary stresses and feminine ending: "his náme was ábsence." The last two lines of the passage constitute a kind of pseudo-couplet: they do not rhyme but are syntactically identical, and both have only two primary stresses although the first has eight syllables and the second, seven. The feminine endings and oddly infrequent stresses give this couplet a harsh, jagged effect:

Fámily of anthólogists!

Colléctors of ínjuries!

To take another example of Kunitz's superb manipulation of sound patterns, let us look at Part 5 of "Journal":

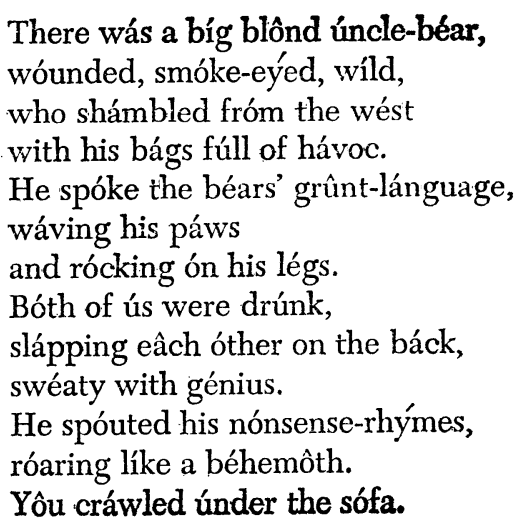

In the first line, the regular iambic beat gives way to emphatic stresses clustering together: it sounds like the beginning of "Goldilocks and the Three Bears." But the fairytale mood is rapidly dissipated in the second line; the reversal of rhythm, two caesurae, and alliterating $d$ 's and $w$ 's bring in an ominous note: "Wónded,// smóke-êyed,// wild." Again, the expectations set up in the third line, which is made up of three iambs, are destroyed in the fourth, in which Kunitz places the three primary stresses on syllables containing harsh stops, fricatives, and two nasal $a$ 's: "with his bágs fúll of hávoc." The unpleasant sexual undertone of the 
line is thus emphasized. One should note further that the $k$ sound in "havoc" is repeated in "smoke," "spoke," "rock-," "drunk," "back," and "crawled"-all words that intensify the manic excitement of the stranger. The baby girl's fear and disgust is conveyed by the falling rhythm of the last line: "Yôu cráwled únder the sófa."

When one turns from such particular sound patterns to the poem's larger structure, one notes that the nine sections of "Journal for my Daughter" have a definite progression: the roles of the two protagonists are gradually reversed. The poem opens with the daughter's complaint, as it is verbalized by her father, but at the end, the reader understands that it is the father who is in fact the dependent member of the couple. After making the grand gesture in Part 2 of offering to measure the depths of his affection for his daughter, even as chipmunks and field mice measure the amount of food they have collected for the winter, he imperceptibly comes to terms with the truth that perhaps she no longer cares as much as he does.

Thus his memories have an odd way of backfiring on him. Proudly recalling how he sang his daughter to sleep in her infant days, he notes that "the only tune/ I ever learned to carry" was "There were three crows/ sat on a tree. ..." It is ironic that he should remember this particular ballad, for it concerns a slain knight, whose corpse, deserted by his hawk, his hound, and his lady fair, is devoured by the rapacious crows. Had the poet's desertion of his daughter left her to a similar fate? Or again, in Part 5 the poet is forced to admit that his disorganized life-style, epitomized by his drunken session with his friend, the sweaty, bear-like genius (surely Theodore Roethke?), did not exactly make for the ideal environment in which to bring up small children. But the most touching irony in the poem is that, as she grows up, the speaker's daughter espouses his ideals with a vengeance. A perfect Spock father, the poet, parodying Eliot's Gerontion ("Goodies are shaken/ from the papa tree"), ruefully remembers that he preached the gospel of self-reliance to his daughter: "Be what you are. Givel what is yours to give./ Have style. Dare." But "such a storm of fortune cookies" has its dangers. As the daughter grows up to become "radical, young, desirable, cool," her father is left standing on the sidelines, insisting, "What do I want of my life?/ More! More!" The gulf between his liberalism, epitomized by his cry of "Noli me tangere?", and her radical poster, bearing the misspelled slogan, "Don't tred on me!", is too wide to bridge.

Puzzling over the troubled world of the present, the father's mind circles back to the past, to "the summer I went away." Two things happened during that summer of divorce: the little girl's dog was run over and she witnessed her first lunar eclipse:

One night I carried you outdoors, in a blitz of fireflies, to watch your first eclipse.

Your far-off voice, drugged with milk and sleep, said it was a leaf sliding over the light. 
Both of these events symbolize, perhaps a shade too obviously, the removal of the father from the child's world. The leaf sliding over the light refers not only to the moon's eclipse but to his as well, and the "shallow grave" turns out to be his own. What then remains? In the ninth and final section, Kunitz alludes to Coleridge's famous passage about Hartley's infant sorrow in "The Nightingale":

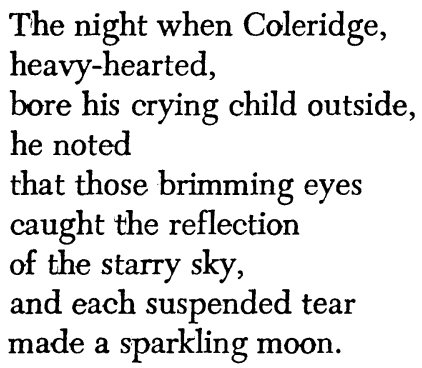

Like Coleridge's guilty love for Hartley, the poet's relationship with his daughter has not been an easy or a carefree one, but, the poem implies, the bond between the two is nevertheless too strong to be broken. Out of pain and suffering ("each suspended tear") comes a "sparkling moon," promising renewal.

"Journal for my Daughter" is not without flaws. Sometimes the poem builds to a seeming climax only to go limp, as in the concluding lines of Part 4 , which rather pointlessly parody Prufrock's final realization that the mermaids will not sing to him:

You do not need to sing to me.

I like the sound of your voice

even when you phone from school

asking for money.

Since most daughters phone from school to ask for money, these lines add little to our understanding of the girl's predicament. Surely something more telling, more concrete is required at this juncture in the poem. Similar objections may be raised to Part 8 . I am at a loss to explain the symbolic import of the Pekinese dog, "Ko-San,/ half mandarin, half mini-lion." Perhaps Kunitz wants to suggest that the father himself is a kind of half-caste, a bundle of contradictions, but I cannot see that much would be lost if the dog were, say, a Labrador Retriever. The symbolic prelude to the father's imminent "death," moreover, is all too predictable.

Oocasionally, too, Kunitz resorts to the clever but ultimately empty verbalism that detracted from his early poems. Thus the girl is reminded that, wherever she may turn, "in the fugues of appetite,/ in the groin of nightmare," the shadow of her father will haunt her. "Fugues of appetite" and "groin of nightmare" are merely portentious phrases that tell us nothing about love or pain. Or, to take another example, the mathematical metaphor in the following lines is merely cute: 
I was happy you were born, your banks of digits

equipped for decimals. ...

These strictures aside, "Journal for my Daughter" is a memorable and highly accomplished poem, a delicately humorous Jewish version of Lowell's Life Studies poems. One has the sense that, like Bellow's Herzog, Kunitz's father cannot understand how he, who would be willing to kiss his daughter's feet, should end up in such a painful position vis-a-vis the person he loves most. If "Journal for my Daughter" lacks the Lowellian resonance, it is redeemed by a toughness and vitality that is absent in the family poems of such confessional poets as Snodgrass, Anne Sexton, or Anthony Hecht.

The strengths and weaknesses I have isolated for discussion in considering "Journal for my Daughter" are, I think, typical of the whole volume. First, a few words about Kunitz's prosody. The verse form of "Journal"-the three-stress line with variations, arranged in irregular verse paragraphs-is used again in "King of the River," "Robin Redbreast," "After the Last Dynasty," "The Portrait," and "The Testing Tree." In the last-mentioned poem, Kunitz arranges the lines in triads, somewhat in the manner of Williams" "Desert Music," but in "The Testing Tree" this device is merely distracting for the speaker's meditation is continuous, and there is no real reason to chop it up into separate visual entities. In most of the poems, however, Kunitz's mastery of the three-stress line is striking. The concluding passage of "After the Last Dynasty," for example, has the tone of direct, colloquial speech-no two lines are rhythmically identical-yet the verse is never flat because recurrent $p$ 's and $t$ 's, short and long $i$ 's, and, in the last three lines, $d$ s and $l$ 's are carefully interrelated:

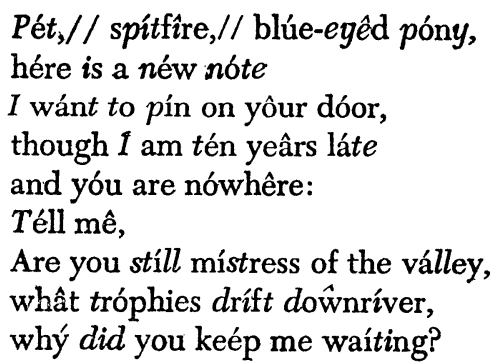

When Kunitz does use a loose blank verse in The Testing Tree, as, for example, in "Indian Summer at Land's End," and "River Road," it seems a much more flexible and functional medium than the blank verse of "The Science of Night" or "Father and Son" in Selected Poems. If "Indian Summer" had fourteen lines rather than twenty, anyone might mistake it for one of the sonnets in Lowell's Notebook, but I am not sure Kunitz's poem is not better than, say, the twelfth Harriet sonnet which begins: "Everyone now is crowding everyone/ to put off leaving till the Indian Summer. . . ." These lines seem relatively slack when compared to: 
The seáson stálls,// unseásonábly fáir, blúe-faîr,// seréne,// a stáck of gólden díscs, each dísc a dáy,// and the addítion slów.

Here the end-of-season inertia which is Kunitz's theme is perfectly rendered by the polysyllables, secondary stresses, strong pauses, the alliteration of s's and d's, and the repetition of each key item in a slightly altered context: "season"-"unseasonably"; "fair"-"blue-fair"; "golden discs"-"each disc a day."

A second virtue of The Testing Tree is Kunitz's witty and imaginative treatment of the self-deprecating narrator. The volume's leitmotif could easily be the message that the exasperated father of "Journal" forces his daughter to read: "What do I want of my life?/ More! More?" The speaker who emerges from these poems has no illusions about himself; he is much more humble, more human, and less pretentious than the "I" of the earlier poems. Compare, for example, "Foreign Affairs," a typical poem of Kunitz's metaphysical phase, to the new "After the Last Dynasty." Both poems are built around the same central metaphor: love is war. In both, moreover, this metaphor is elaborated through a whole series of conceits: the battle of the sexes is fraught with attack, counterattack, defense, strategem, retreat. But the tone of the two poems is entirely different. Here is the beginning of "Foreign Affairs":

We are two countries girded for the war,

Whisking our scouts across the pricked frontier

To ravage in each other's fields, cut lines

Along the lacework of strategic nerves,

Loot stores; while here and there,

In ambushes that trace a valley's curves,

Stark witness to the dangerous charge we bear,

A house ignites, a train's derailed, a bridge

Blows up sky-high, and water floods the mines.

Here the assertive "I" seems so pleased with his extravagant comparisons that he finally capitulates to his own cleverness, inventing images that have no metaphoric equivalence, for what physical or mental quality of the lovers can be compared to the ignited house, the derailed train, the blown-up bridge? In "After the Last Dynasty," by contrast, the speaker knows quite well that his central metaphor is ridiculous:

Loving you was a kind of Chinese guerrilla war.

Thanks to your lightfoot genius

no Eighth Route Army

kept its lines more fluid,

traveled with less baggage.

so nibbled the advantage.

Even with your small hard heart 
you made a dance of departures.

In the cold spring rains

when last you failed me

I had nothing left to spend

but a red crayon language

on the character of the enemy. ... .

$(\mathrm{TT}, 28)$

Here the poet mocks his own miscalculations. Despite her seeming weaknessthe lady has a bad heart-his sexual opponent nibbles her advantage and dances out of his life with all the joy of a "light-foot genius," while he, supposedly the strong healthy one, is left holding the red crayon, his futile military weapon against this slippery enemy.

Such delicate self-mockery is found in a number of other poems in the volume. In "The Illumination," the poet makes the grand Eliotic gesture of invoking Dante's spirit as his master, but when the ghost does appear, it is only to put the poet in his place:

"I know neither the time

nor the way

nor the number on the door ...

but this must be my room,

I was here before."

And he held up in his hand

the key,

which blinded me.

(TT, 9)

Similarly, in "Robin Redbreast," the speaker is rather pleased with himself because he has decided to help an injured little robin return "into his element," but just when he is about to let the bird go, his mood of self-satisfaction is suddenly dissipated:

fear clutched my hand,

for through the hole in his head, cut whistle-clean ... .

through the old dried wound

between his eyes

where the hunter's brand

had tunneled out his wits ...

I caught the cold flash of the blue unappeasable sky.

(TT, 22-23)

In the title poem of The Testing Tree, the poet's elaborate ritual game (if he hits the target-oak with his stones, he will win the laurels of love, poetry, and eternal life) is placed in ironic perspective by a particularly unpleasant recurring dream, in which his mother, flanked by Bernard Shaw and Bertie Russell-the two socialist princes-wears "an owl's face/ and makes barking 
noises." When he tries to escape this frightening image, he finds himself peering down into a well and sensing that, if the dirt keeps sifting in, he is the one who will be blamed, even though he has no idea what crime he has committed. Thus an irrational ideal (the superstitious children's game) gives way to a reality which is even more irrational, and the poem moves toward the insight that "In a murderous time/ the heart breaks and breaks."

Sometimes, however, the poet spells out what should be merely implicit with the result that the edge of his irony is blunted. "River Road," for example, in which the poet meditates on the painful turning point in his life when his marriage failed and he had to begin all over again (his rebirth is symbolized by the planting of the forest), ends with the strained lines:

I walk into the woods I made, my dark and resinous, blistered land, through the deep litter of the years.

This is telling not showing. Poetic closure is inadequate because nothing in the poem has prepared us for such an explicit, extraneous statement. Similarly, the charming poem, "The Magic Curtain," whose theme is that the actions we find exciting and moving on the cinema screen are those that we censure and reject in real life, ends on a note of bathos. Frieda, the poet's onetime German nursemaid, with whom he shared such delicious hours at the movies during his childhood, runs away with someone's husband, thus disgracing herself in the eyes of a community that includes the poet's mother:

After the war an unsigned picture-card
from Dresden came, with one word: Liebe.
"I'll never forgive her," mother said,
but as for me, I do and do and do.

$(\mathrm{TT}, 34)$

But since the poem has made perfectly clear all along that the poet has not only forgiven Frieda for her "sins" but that he worships her memory, this sentimental conclusion seems wholly gratuitous.

A related weakness of The Testing Tree is the poet's occasional uncertainty as to how to transfigure the object, how to find the appropriate detail that makes a remembered incident come alive, and how to relate such details into a coherent poetic network. When, for example, the poet's dead father in "Three Floors" is associated with "a red Masonic hat/ and a walking stick," the image fails to suggest why this figure should haunt the boy's dreams: think of all the Jewish immigrant fathers with Masonic hats and walking sticks! The child's troubled response in the final stanza is thus insufficiently motivated:

Bolt upright in my bed that night

I saw my father flying;

the wind was walking on my neck,

the windowpanes were crying.

(TT, 10) 
Another family poem, "The Portrait," begins as follows:

My mother never forgave my father for killing himself

especially at such an awkward time and in a public park

that spring

when I was waiting to be born.

(TT, 57)

Lowell has expressed admiration for the way these lines "seize the subject by the throat," but I wonder if the poem is not too vague, if it does not lack the Chekhovian-or Lowellian-resonance that makes a personal, realistic memoir like this one come alive. I want to know why the father committed suicide. Why was the mother so unforgiving? Why is the boy so attached to the little "pastel portrait" of his father? And why does the mother slap her son merely for showing her the picture? We can answer these questions only by resorting to clichés: fatherless boys relentlessly pursue their lost father image, etc. No larger theme emerges because mother, father, and son stand for nothing larger than themselves. The experience clearly meant something to Kunitz-he can feel his cheek "still burning"-but the poem does not contain the concrete images that would translate the painful memory for the reader.

What one misses in Kunitz's new confessional poetry, in short, is the passionate sense of history that can endow a private incident or public event with universal significance. But perhaps it is unfair to expect Kunitz to write another "Easter 1916" or "Skunk Hour." One should be grateful, at any rate, for the unique blend of humility and firmness that gives The Testing Tree its air of graciousness and good sportsmanship. No contemporary poet is more candid about his own limitations: witness "The Game:"

Let's spin the bottle

No I don't want to be kissed

Sometimes I feel my arm

Is turning into a tree

Or hardening to stone

Past memory of green

I've a long way to go

Who never learned to pray

$O$ the night is coming on

And I am nobody's son

Father it's true

but only for a day 